\title{
Pergeseran Norma Hukum Waris Pada Masyarakat Adat Patrilineal
}

\author{
Sonny D. Judiasih, Afifah Syakira, Natalia Karelina, \\ Noer A. Januariska,Purri Trirani, Zeira Nabilla \\ Fakultas Hukum Universitas Padjadjaran \\ natalkarel@gmail.com
}

Submit: 26-09-2020; Review: 11-12-2020; Terbit: 21-06-2021

\begin{abstract}
In patrilineal system, the familial line is descended from the male side of the family, whereas the female could not be regarded as the heir to the family. This study aims to analyze the change of the norms in patrilineal inheritance system, using legal normative research mainly from literature studies. The result of this study shows that there is a change towards the recognition of the rights of widows and female descendants in terms of inheritance. It is mainly caused by some aspects, such as religions, lifestyles, which weaken the communal attachment, and the increase of women's roles within the family. The changes of the norms are also acknowledged and applied in several yurisprudences, which indicates that they have been legally accepted and therefore function as legal references. However, the changes of the norms is not broadly applied for the whole patrilineal indigenous people, but only within certain groups, in line with the persuasive force of jurisprudence that is acknowledged in Indonesia.
\end{abstract}

\section{Keywords: Adat Law, Inheritance Customary Law, Patrilineal Inheritance Customary Law.}

\begin{abstract}
Abstrak
Sistem kekerabatan patrilineal murni menjadikan anak laki-laki sebagai waris dari pihak bapak, sedangkan anak perempuan tidak dapat berkedudukan sebagai ahli waris. Namun, seiring dengan perkembangan yang ada terdapat perubahan kedudukan laki-laki dan perempuan dalam lingkup keluarga maupun masyarakat. Penelitian ini bertujuan mengkaji pergeseran corak/norma hukum waris adat patrilineal akibat perubahan-perubahan yang terjadi. Metode penelitian yang digunakan adalah yuridis normatif dengan mengutamakan penelusuran literatur. Hasil penelitian menunjukan bahwa terjadi pergeseran norma hukum waris adat dalam masyarakat patrilineal yang mengakui kedudukan anak perempuan sebagai ahli waris dan janda sebagai pihak yang berhak atas harta warisan suaminya. Pergeseran tersebut didasarkan pada beberapa aspek seperti pengaruh agama, perkembangan gaya hidup yang mengakibatkan menurunnya ikatan komunal, dan peningkatan peran perempuan di dalam keluarga. Pengakuan kedudukan anak perempuan dan janda ketika terjadi pewarisan diakui dalam beberapa putusan, sehingga beberapa putusan tersebut merupakan yurisprudensi dan dapat menjadi suatu acuan hukum yang menggambarkan terjadinya pergeseran hukum waris adat patrilienal. Namun, pergeseran norma hukum waris adat patrilineal tersebut hanya terjadi di beberapa kelompok/kalangan tertentu saja tergantung pada perkembangan budaya serta kebutuhan dari kalangan yang
\end{abstract}


bersangkutan sesuai dengan prinsip persuasive force of precedent yang berlaku di Indonesia.

\section{Kata Kunci: Hukum Adat, Hukum Waris Adat, Hukum Waris Adat Patrilineal.}

\section{Pendahuluan}

Pada dasarnya pewarisan adalah suatu perpindahan segala hak dan kewajiban seseorang yang meninggal kepada para ahli warisnya. Adapun pengertian dari hukum waris adalah hukum yang mengatur tentang peralihan harta kekayaan yang ditinggalkan seseorang yang meninggal serta akibatnya bagi para ahli warisnya (Effendi Perangin, 2018:3 ).

Hukum waris di Indonesia bersifat pluralistik, yakni terdapat hukum waris Eropa (menurut Kitab Undang-Undang Hukum Perdata), hukum waris Islam, dan hukum waris adat. Adanya pluraristik hukum tersebut tidak dapat dilepaskan dari adanya pembagian hukum dan golongan pada masa penjajahan (Pasal 131 dan Pasal 163 Indische Staatregeling) sehingga hukum waris Barat berlaku untuk golongan Eropa dan Timur Asing Tionghoa sedangkan hukum waris adat berlaku bagi golongan
Bumiputera. Untuk masyarakat yang beragama Islam, maka hukum waris Islam juga dapat diberlakukan. Setelah Indonesia merdeka, maka pada dasarnya ketentuan hukum yang berlaku pada masa penjajahan tetap diberlakukan selama belum ada peraturan terbaru yang mengaturnya sebagaimana dinyatakan dalam Pasal I Aturan Peralihan Undang-Undang Dasar 1945 (UUD 1945). Dengan demikian, hukum waris adat masih dapat diberlakukan bagi masyarakat golongan Bumiputera di Indonesia. Pemberlakuan hukum adat di Indonesia juga diakui sebagaimana dalam Pasal 18B ayat (2) UUD 1945 sepanjang masih hidup dan sesuai dengan perkembangan dan prinsip Negara Kesatuan Indonesia.

Sistem kewarisan di indonesia tidak dapat dipisahkan dari sistem kekeluargaan yang ada di masingmasing masyarakat hukum adat (Sonny Dewi Judiasih, Hazar Kusmayanti, dan Deviana Yuanitasari, 2020 : 68). Hukum adat 
di Indonesia memiliki 3 (tiga) sistem kekeluargaan yaitu patrilineal, matrilineal, dan parental. Dengan demikian, hukum waris adat itu sendiri bersifat pluralistik dikarenakan terdapat sistem kekerabatan yang berbeda. Sistem kekeluargaan patrilineal menarik sistem keturunan dari garis keturunan ayah atau leluhur laki-laki. Pada sistem kekeluargaan matrilineal, ditarik garis keturunan dari ibu atau keturunan leluhur perempuan. Sedangkan sistem parental menarik garis keturunan baik dari pihak ayah maupun ibu, sehingga pada sistem ini tidak ada perbedaan antara kedudukan ayah maupun ibu. Hukum waris adat juga memperhatikan asas kesamaan hak, kerukunan dan kekeluargaan, ke Tuhanan, musyawarah dan mufakat, dan keadilan serta parimirma. (Hilman Hadikusuma, 2015 : 21). Perpindahan harta warisan harus mampu dilakukan dengan jalan kekeluargaan, dengan menjadikan musyawarah dan kebersamaan sebagai rujukannya.

Hukum adat merupakan salah satu sumber hukum yang penting dalam rangka pembangunan hukum nasional yang menuju ke arah peraturan perundang-undangan. Unsur-unsur kejiwaan hukum adat yang berisikan kepribadian bangsa Indonesia perlu dimasukkan ke dalam peraturan hukum baru agar hukum yang baru itu sesuai dengan dasar keadilan dan perasaan hukum masyarakat Indonesia. Beragam permasalahan yang timbul dalam kehidupan masyarakat tersebut sudah pasti menghendaki pemecahan atau solusi yang secepat dan segera mungkin dalam rangka menjaga kenyamanan dan ketenteraman itu sendiri (Bravo Nangka, 2019 : 145).

Hukum adat pada satu sisi akan berhadapan, berkompetensi, saling mempengaruhi, atau bahkan bergerak mendekat pola-pola baru (Sonny Dewi Judiasih, Hazar Kusmayanti, dan Deviana Yuanitasari, 2020 : 84). Dewasa ini terdapat perubahan nilai-nilai dan pola pikir dalam masyarakat, khususnya dalam masyarakat patrilineal terkait hak dan kedudukan perempuan di dalamnya. Pada mulanya pewarisan patrilineal ditujukan kepada anak laki-laki 
dikarenakan anak laki-laki memiliki peran dan tanggung jawab yang besar sebagai penerus garis keturunan keluarga dan pengganti kedudukan bapak. Hal tersebut tidak demikian dengan isteri maupun anak perempuan, sehingga terhadap mereka tidak diberi hak apapun. Dengan berkembangnya gaya hidup dan pola pikir masyarakat, maka beberapa masyarakat adat tidak lagi menerapkan corak-corak perilaku dan hukum adat sepenuhnya seperti masyarakat terdahulu. Peran dan kedudukan isteri serta anak perempuan secara sosial budaya mengalami perubahan, dimana isteri dan anak perempuan turut memiliki peran dalam mengurus kepentingan keluarga. Selain daripada itu, terdapat pula beberapa putusan atau yurisprudensi yang juga mengakui kedudukan anak perempuan dan janda dalam hal pewarisan pada perkembangannya, mulai dari Putusan Mahkamah Agung Nomor No. 179/K/Sip/1961 di tahun 1961 hingga putusan yang di tahun-tahun terakhir ini dikeluarkan seperti contohnya Putusan Nomor 35/PDT/2016/PT.DPS. Putusan- putusan tersebut pada dasarnya mengakui hak anak perempuan sebagai ahli waris, mengakui hak janda atas harta gono gini, atau mengakui hak janda sebagai ahli waris dari suaminya. Hal itu menunjukkan bahwa pergeseran norma hukum waris adat patrilineal memang terjadi dan diakui menurut hukum bahkan hingga saat ini. Penelitian dalam rangka pembuatan artikel ini mengkaji lebih lanjut mengenai pergeseran norma-norma hukum waris adat patrilineal pada masyarakat adat tersebut, khususnya yang berkaitan dengan masyarakat patrilineal Bali, Batak, dan Lampung, terkait hak dan kedudukan anak perempuan dan isteri/janda dalam hal pewarisan. Dengan demikian, identifikasi masalah yang akan dibahas adalah: 1) Bagaimana pergeseran norma hukum waris pada masyarakat adat patrilineal, terutama dalam kaitannya dengan kedudukan serta hak anak perempuan maupun janda dalam pewarisan?

Bagaimana pengaruh yurisprudensi terhadap pergeseran hukum waris pada masyarakat adat patrilineal? 


\section{Metode Penelitian}

Untuk mengkaji permasalahan diatas, maka jenis penelitian yang digunakan dalam penulisan ini adalah penelitian yuridis normatif yang mengutamakan penelusuran literatur, dengan pendekatan perundang-undangan, pendekatan konsep, dan pendekatan historis. Bahan-bahan hukum yang diperoleh, dikumpulkan, dan disusun secara sistematis selanjutnya dianalisis dan dikaji keterkaitannya satu sama lain.

\section{Hasil dan Pembahasan}

\section{Pergeseran Norma Hukum Waris}

\section{Adat Patrilineal Terkait}

\section{Kedudukan Anak Maupun Janda}

\section{a) Masyarakat Adat Bali}

Sesuai hukum adat yang berlaku, sistem kekerabatan di Bali adalah patrilineal (Wahyu Satria Wana Putra Wijaya, Agung Basuki Prasetyo, dan Triyono, 2016 : 2). Anak laki-laki di Bali berkedudukan sebagai "purusa" atau "kapurusa", yang merupakan ahli waris garis keturunan ayah. Anak perempuan dapat menjadi ahli waris apabila dia berkedudukan sebagai sentana, hal mana terjadi apabila seorang ayah hanya memiliki keturunan perempuan. Anak sulung pria memiliki tanggung jawab sebagai kepala rumah tangga, baik dalam kedudukan adat maupun terhadap kekayaan keluarganya (Hilman Hadikusuma, 2015 : 73).

Anak sulung pria pada dasarnya memiliki kedudukan sebagai pengganti orang tua yang telah meninggal dalam mengurus keluarga (Ni Luh Gede Praresti Dangin, 2015 : 8). Anak perempuan akan meninggalkan keluarga dan masuk ke dalam keluarga suaminya. Atas dasar itu dapat dipahami mengapa pada dasarnya masyarakat adat Bali tidak mewariskan hartanya kepada anak perempuan.

Kedudukan dan peran kaum perempuan dalam keluarga masyarakat Bali semakin berkembang di mana mereka turut serta dalam mencari nafkah, mengurus, serta mengambil keputusan bagi keluarga. Di sisi lain, hal itu menyebabkan peran dan tanggung jawab laki-laki tidak sebesar masyarakat adat Bali terdahulu. Terlebih di masyarakat 
modern saat ini, terdapat penurunan tingkat kepatuhan terhadap pelaksanaan kaidah-kaidah hukum adat yang menyebabkan ada beberapa tanggung jawab adat yang tidak dilaksanakan seperti halnya masyarakat terdahulu. Perkembangan peran perempuan dalam hubungan kekeluargaan masyarakat Bali nampak bahwa: perempuan memiliki kontribusi sebesar $46,5 \%$ terhadap ekonomi keluarga, perempuan dengan ekonomi kelas menegah ke bawah memiliki kontribusi sebesar $65 \%$ untuk keluarga, dan perempuan dengan ekonomi kelas menengah ke atas memiliki kontribusi sebesar 49\% untuk keluarga (Putra Astiti dan tim dalam Ni Ketut Sri Utari, 2006 : 78).

Selain hukum adat, gaya hidup dan kepercayaan masyarakat di Bali juga didasarkan pada ajaran agama Hindu. Kedudukan perempuan, yakni ibu dan anak-anak perempuan, diakui dan dihormati dalam ajaran agama Hindu, sebagaimana tercantum dalam Bab III Sloka 58 dan 59 serta Bab IX. 96 Kitab Suci Manawa Dharmacastra.
Perkembangan gaya hidup dan peran perempuan perlu untuk turut disertai dengan perkembangan kaidah hukum termasuk hukum adat, berdasarkan asas yang dianut dalam hukum adat itu sendiri seperti asas kesamaan hak, asas kerukunan/kekeluargaan, dan asas keadilan. Bukti adanya pergeseran norma hukum waris adat dalam masyarakat Bali itu sendiri adalah dengan dikeluarkannya keputusan Majelis Ulama Desa Pakraman Bali dengan Keputusan Pasamuhan Agung III MUDP Bali Nomor 01/Kep/PSM-3/MDP.Bali/X/2010 tanggal 15 Oktober 2010. Beberapa poin-poin dari keputusan itu adalah: (Wahyu Satria Wana Putra Wijaya, Agung Basuki Prasetyo, Triyono, 2016 : 4-5) :

1) suami dan isteri memperoleh hak yang sama terhadap harta gunakaryanya (harta bersama yang diperoleh selama perkawinan); 2) Anak kandung (perempuan) serta anak angkat (perempuan) yang belum kawin pada dasarnya mempunyai kedudukan yang sama terhadap harta gunakarya orang tuanya, setelah dikurangi sepertiga 
sebagai duwe tengah (harta bersama) untuk dikuasai oleh anak yang melanjutkan swadharma dan tanggung jawab orang tuanya.

Keputusan MUDP Bali tersebut juga diakui dan diterapkan di beberapa desa yakni Desa Pakraman Kesiman, Pakraman Sumerta, dan Pakraman Panjer (Wahyu Satria Wana Putra Wijaya, Agung Basuki Prasetyo, Triyono, 2016 : 5). Melalui Keputusan Pasamuhan Agung III MUDP Bali Nomor 01/Kep/PSM3/MDP.Bali/X/2010 tersebut, maka dapat dilihat bahwa terdapat sekelompok masyarakat Bali yang sudah mengakui hak janda dan anak perempuan sebagai bentuk perkembangan living law dari hukum waris adat Bali sesuai perkembangan nilai sosial budaya dari masyarakat itu sendiri. Perkembangan itu, meskipun dilakukan oleh sekelompok masyarakat, telah menunjukkan pergeseran norma hukum waris patrilineal di Bali yang semula hanya mengutamakan hak waris adat bagi anak laki-laki. Hal itu sesuai dengan sifat hukum adat yang memang tidak tertulis dan dinamis (Sulastriyono dan Sartika Intaning
Pradhani, 2018: 450), sehingga tidak bersifat rigid terhadap perubahan di masyarakat.

\section{Masyarakat Adat Lampung}

Masyarakat adat Lampung menganut sistem kekerabatan patrilineal dimana garis kekerabatannya ditarik berdasarkan garis keturunan laki-laki, sehingga anak perempuan tidak mewaris. Menurut Wirjono, janda perempuan di Lampung tetap merupakan bagian dari keluarga suami, dan dengan demikuan pada umumnya janda perempuan itu tidak akan terlantar dan akan tetap menikmati barangbarang yang ditinggalkan oleh suaminya yang wafat (Hilman Hadikusuma, 2015 : 84-85).

Sekarang ini banyak masyarakat adat Lampung memberikan harta warisan kepada anak laki-laki maupun anak perempuan, terlebih mengingat sifat hukum adat yang bersifat dinamis. Keberadaan serta tumbuh dan berkembangnya hukum adat seiring dengan masyarakat tersebut. (GT Muzainah, 2014: 15). Berdasarkan pengamatan salah satu penulis, Afifah Syakira, sebagai 
penduduk asli Lampung, kasus seperti ini sudah banyak terjadi di daerah Lampung itu sendiri, seperti di daerah Kotabumi, Lampung Utara. Di daerah Kotabumi, Lampung Utara, terdapat beberapa keluarga yang memberikan harta warisan kepada anak perempuannya. Begitu pula dengan masyarakat adat Lampung yang sudah merantau ke luar kota, dimana ikatan komunal dan patrilineal tidak lagi sekuat seperti masyarakat adat terdahulu dikarenakan perbedaan jarak/tempat dan perkembangan kultur serta kebutuhan masyarakat itu sendiri. Namun demikian, belum ada pergeseran norma yang signifikan untuk kedudukan janda sebagai ahli waris dalam masyarakat adat Lampung. Selain itu, untuk beberapa masyarakat Lampung, pembagian harta warisan didasarkan pada hukum waris Islam atau dapat dipengaruhi oleh hukum waris Islam yang pada dasarnya tidak hanya mengakui hak anak laki-laki saja.

\section{Masyarakat Adat Batak}

Hukum waris adat masyarakat Batak menganut sistem patrilineal, sehingga yang berhak mewaris adalah anak laki-laki. Dalam hal-hal tertentu, pihak perempuan bisa saja mendapatkan harta dari keluarganya, misalnya dari orang tua dan/atau saudaranya, yang diperoleh atas dasar pemberian tetapi tetap tidak dalam kedudukannya sebagai ahli waris.

Dalam sistem Patrilineal, isteri yang menjadi janda juga tidak berkedudukan sebagai ahli waris. Janda hanya memiliki hak untuk menikmati, mengambil manfaat, dan mendapatkan nafkah dari harta peninggalan suami, bahkan janda tersebut dapat menikah dengan saudara dari suaminya. Hal itu dikarenakan akibat perkawinan jujur, janda sudah menjadi bagian dari keluarga suaminya sehingga ia akan diurus oleh keluarga suaminya. Pada umumnya, isteri dalam masyarakat patrilineal juga tidak diakui haknya sebagai pemilik harta bersama atau harta pencaharian yang diperoleh selama perkawinan (harta gono gini). Hilman Hadikusuma menyatakan bahwa di lingkungan masyarakat patrilineal seperti di Batak, Lampung, dan Bali, pada dasarnya 
semua harta pencaharian di dalam perkawinan adalah dikuasai suami, termasuk harta asal dan harta-harta pemberian yang didapat isteri (Hilman Hadikusuma, 2015 : 61).

Pada umumnya masyarakat Batak menganut agama Kristen Protestan, Kristen Katolik, maupun Islam. Perilaku dan norma yang berlaku di masyarakat sangat erat dengan keyakinan menurut agama yang diyakini oleh masyarakat setempat, sehingga hukum adat yang berlaku seringkali dipengaruhi kepercayaan dan agama masyarakat tersebut. Sifat hukum adat yang lain adalah kebersamaan, dimana kepentingan bersama diutamakan dibandingkan kepentingan perorangan. Sifat kebersamaan tersebut juga ditemukan dalam masyarakat adat Batak. Prinsip kebersamaan ini selaras dengan prinsip dalihan natolu, ialah tungku tempat memasak yang diletakkan di atas dari tiga batu yang sama besar, sama jarak, dan sama tinggi (Jaja Ahmad Jayus, 2019 : 238). Prinsip kebersamaan tersebut juga seringkali merupakan dasar dari pergeseran norma hukum waris adat yang mengarah pada pengakuan hak perempuan.

Dalam masyarakat Batak khususnya yang non muslim, terjadi perubahan/pergeseran norma pewarisan patrilineal dimana janda maupun anak perempuan dapat diakui haknya ketika terjadi pewarisan. Perkembangan kaidah hukum waris adat Batak itu juga didasarkan karena perubahan dan perkembangan gaya hidup, modernisasi, migrasi suku Batak, dan juga peningkatan peran perempuan dalam mengurus keluarga. Urbanisasi, revolusi, pendidikan, dan kekacauan ekonomi menimbulkan dampak tersebut (Daniel S. Lev, $2018: 1-2)$.

Dengan adanya urbanisasi atau migrasi misalnya, keluarga inti yang berada dalam satu lingkungan yang sama lebih diutamakan dan sebaliknya keterikatan masyarakat adat dengan keluarga besardi kampung halamannya tidak lagi sekuat masyarakat adat Batak terdahulu. Ikatan masyarakat adat yang semakin melemah tersebut juga menimbulkan lemahnya ketaatan terhadap hukum adat. Migrasi, 
modernisasi, dan urbanisasi juga mengakibatkan janda hidup terpisah dengan keluarga besar suaminya sehingga hal itu menghambat pengurusan janda oleh keluarga besar suami. Dengan adanya perkembangan dan perubahan kebutuhan tersebut, maka hak janda sebagai pemegang harta gono gini maupun sebagai ahli waris semakin diakui. Pengakuan hak janda maupun anak perempuan dikarenakan adanya perubahan kebutuhan serta budaya masayrakat itu juga pada dasarnya sesuai dengan prinsip kebersamaan dalam hukum adat tersebut yang mengutamakan kepentingan dan keadilan bagi seluruh pihak sesuai kebutuhannya.

Pada masyarakat Batak Karo misalnya, tidak dapat dipungkiri bahwa saat ini suami dan isteri bekerja sama untuk memenuhi kebutuhan rumah tangga, dimana dalam beberapa daerah peran perempuan di dalamnya juga cukup besar dalam hal mencari nafkah (Sonny Dewi Judiasih, Hazar Kusmayanti, dan Deviana Yuanitasari, 2020 : 76). Dengan demikian, dalam kenyataan dan perkembangannya, perempuan memiliki peran dalam keluarga. Hal tersebut merupakan salah satu faktor yang mendasari adanya pengakuan hak perempuan dalam masyarakat adat tersebut.

Pada kenyataannya telah timbul beberapa persoalan dan keberatan mengenai kedudukan janda maupun anak perempuan Batak yang berujung kepada sengketa di pengadilan. Dengan melihat pada perubahan nilai sosial budaya dan perkembangan kebutuhan pada masing-masing kasus tersebut, maka beberapa hakim menetapkan bahwa anak perempuan dapat berkedudukan sebagai ahli waris dan janda dapat berkedudukan sebagai pemegang harta gono gini maupun sebagai ahli waris. Pembahasan putusan akan dijelaskan lebih lanjut pada sub pembahasan berikutnya, namun dapat dilihat bahwa dari berbagai putusan tersebut telah terdapat pergeseran pandangan menyebabkan perubahan keberlakuan hukum waris adat bagi beberapa pihak/masyarakat Batak tertentu. Putusan-putusan tersebut merupakan bukti bahwa masyarakat Batak dalam 
kenyataannya bergerak menuju perubahan pola pikir yang lebih modern dan mengutamakan persamaan kedudukan antara lakilaki dan perempuan, dimana hal tersebut dipengaruhi berbagai faktor yang secara perlahan menggambarkan suatu perkembangan (Sonny Dewi Judiasih, Hazar Kusmayanti, dan Deviana Yuanitasari, 2020 : 78).

Selain diakibatkan karena perkembangan sosial budaya serta kebutuhan masyarakat, norma hukum waris adat patrilineal juga bergeser karena dipengaruhi oleh norma serta nilai-nilai agama seperti dalam hukum Islam. Beberapa masyarakat adat Batak menganut hukum Islam. Dalam beberapa masyarakat adat yang beragama Islam, hukum waris Islam dapat dipakai untuk mengatur masalah pewarisan. Hukum waris Islam juga banyak digunakan khususnya oleh masyarakat adat yang telah mengalami urbanisasi, modernisasi, maupun migrasi. Hal itu dikarenakan keterikatan masyarakat adat terhadap ikatan serta kaidah-kaidah hukum adat semakin menurun, namun agama justru tetap dipraktekkan dan diyakini dimanapun berada. Namun bagi masyarakat yang tetap menggunakan hukum waris adat, konsep pewarisan dalam hukum Islam juga dapat turut mendasari perubahan pola pikir dan melatarbelakangi pergeseran norma hukum waris adat sehingga lebih condong ke arah pengakuan kedudukan perempuan dalam pewarisan. Dalam hukum Islam, anak perempuan dan janda tidak saja diakui sebagai ahli waris, namun lebih dari itu, ajaran agama juga menetapkan porsi bagian untuk mereka berdua. Ketentuan Al-Quran yang menempatkan anak perempuan dan janda sebagai ahli waris sesungguhnya juga merupakan perubahan dalam masyarakat Arab yang pada dasarnya menganut kekerabatan patrilineal (Khalil Abdul Karim, 2003 : 33-46). Beberapa masyarakat menganggap bahwa sistem pewarisan yang demikian lebih sesuai dengan nilai-nilai budaya dan keadilan pada masyarakat tersebut, karena apabila menggunakan hukum adat sekalipun keluarga ayah seringkali tetap saja 
memberi sejumlah harta hibah kepada anak perempuannya.

\section{Pengaruh Yurisprudensi Dalam} Pergeseran Hukum Waris Adat Masyarakat Patrilineal

Pergeseran norma hukum waris adat patrilineal yang mengarah kepada pengakuan hak dan kedudukan janda maupun anak perempuan juga dinyatakan dan diakui dalam beberapa putusan atas kasus-kasus tertentu, yang kemudian diakui menjadi yurisprudensi. Putusan-putusan tersebut menunjukkan bahwa pada kenyataannya telah terdapat perubahan pandangan serta kebutuhan dari beberapa pihak yang pada akhirnya membuat hakim memutuskan bahwa perlu adanya perubahan norma atau kaidah hukum waris adat patrilineal terhadap pihakpihak yang bersangkutan tersebut. Hal ini menunjukkan bahwa pada prakteknya telah terjadi pergeseran norma hukum waris adat patrilineal meskipun tidak menyeluruh dan hanya menyangkut beberapa kalangan tertentu.
Persoalan kedudukan anak perempuan Batak Karo sebagai ahli waris sempat diajukan ke Pengadilan Negeri Kabanjahe, Pengadilan Tinggi, sampai kasasi ke Mahkamah Agung. Pada tanggal 23 Oktober 1961 keluarlah putusan Mahkamah Agung No. 179/K/Sip/1961 yang menolak kasasi yang diajukan penggugat (R. Subekti, 1991 : 1516).

Pada intinya, putusan Mahkamah Agung tanggal 1 Nopember $\quad 1961 \quad$ Nomor 179/K/Sip/1961 tersebut menyebutkan bahwa berdasarkan rasa perikemanusiaan dan keadilan umum dan atas hakikat persamaan hak antara laki-laki dengan perempuan, sekaligus mempertimbangkan hukum yang hidup di seluruh Indonesia, bahwa anak perempuan, sebagaimana anak laki-laki, harus diposisikan sebagai ahli waris dan memiliki kedudukan yang sama. Keputusan tersebut dibuat Mahkamah Agung khususnya untuk masyarakat Karo, namun Mahkamah Agung menganggap kaidah hukum tersebut merupakan kaidah hukum yang hidup di seluruh 
Indonesia (Hilman Hadikusuma, 2015 : 136). Putusan tersebut merupakan suatu terobosan atas hak waris anak perempuan Karo yang semula sama sekali tidak diakui, dan sering dijadikan rujukan atau yurisprudensi oleh putusan lainnya. Putusan tersebut dilandasi oleh TAP MPR Nomor II Tahun 1960, dan menurut Subekti merupakan tonggak bersejarah untuk pencapaian persamaan hak dan kedudukan antara wanita dan pria (Sonny Dewi Judiasih, Hazar Kusmayanti, dan Deviana Yuanitasari, 2020: 77). Hal itu terbukti bahwa setelah putusan tersebut dikeluarkan, beberapa pihak mulai berani menyuarakan haknya melalui jalur pengadilan untuk memperoleh persamaan kedudukan tersebut (Sonny Dewi Judiasih, Hazar Kusmayanti, dan Deviana Yuanitasari, 2020 : 77).

Beberapa putusan (dari yang terdahulu hingga terbaru) yang mengakui hak dan kedudukan anak perempuan sebagai ahli waris dalam masyarakat patrilineal, khususnya $\mathrm{d}$ Bali adalah:
1) Putusan tanggal 14 Juni 1968 Mahkamah Agung Nomor 100 K/Sip/1967

“...karena mengingat pertumbuhan masyarakat dewasa ini yang menuju kearah persamaan kedudukan antara pria dan wanita, dan penetapan janda sebagai ahli waris telah merupakan yurisprudensi yang dianut oleh Mahkamah Agung”.

2) Putusan Mahkamah Agung tanggal 2 Nopember 1976 Nomor 284K/Sip/1975

"Menurut Hukum Adat baru istri dan anak-anak perempuan adalah ahli waris".

Putusan tersebut dikutip sebagai bahan pertimbangan Pengadilan Tinggi Denpasar dalam Putusan Nomor 35/PDT/2016/PT DPS, dimana kaidah yang tersebut dianggap berlaku sebagai hukum adat yang ada bagi masyarakat Bali.

3) Putusan Mahkamah Agung RI Nomor 4766 K/Pdt/1998 tanggal 16 Nopember 1999

"Perempuan di Bali berhak atas harta peninggalan dari pewaris, walaupun sistem pewarisan di 
Bali sendiri mengenal sistem pewaris mayorat laki-laki."

4) Putusan Pengadilan Tinggi Denpasar tanggal 23 Pebruari 2016 Nomor 35/PDT/2016/PT DPS

"Mengingat perubahanperubahan atau perkembangan masyarakat Bali, yang mengakui persamaan kedudukan Pria dan Wanita di banyak bidang, serta asas keadilan dan kemanfaatan, Majelis Hakim Pengadilan Tinggi Denpasar berpendapat bahwa perempuan di Bali berhak mewaris dari orang tuanya..."

Putusan ini merupakan salah satu putusan terbaru yang dikeluarkan di tahun 2016. Putusan ini pada dasarnya menunjukkan bahwa pergeseran norma hukum waris masyarakat Bali yang diakui dalam yurisprudensi tahun 1961, 1967, 1975, maupun 1999 di atas masih dapat dipandang sebagai suatu norma yang berlaku bagi kalangan tertentu dewasa ini.

Dalam hal kedudukan janda sebagai pemegang harta gono gini dan ahli waris, beberapa putusan juga menerapkan suatu norma dimana janda dari masyarakat patrilineal pada dasarnya berhak atas bagiannya ketika terjadi pewarisan. Putusan Mahkamah Agung tanggal 17 Januari 1959 Nomor 320 K/Sip/1958 menyatakan bahwa menurut hukum adat Tapanuli pada perjalanan zaman pada waktu sekarang seorang isteri dapat mewarisi pencaharian dari suaminya dan Putusan Mahkamah Agung tanggal 9 April 1960 Nomor 120 K/Sip/1960 yang pada dasarnya menyatakan bahwa, "Harta pencaharian harus dibagi sama rata antara suami-isteri." Salah satu putusan terbaru yang mengakui hak isteri sebagai pemilik dari harta bersama dalam masyarakat patrilineal adalah Putusan Pengadilan Tinggi Denpasar Nomor 35/PDT/2016/PT.DPS yang menyatakan pada pokoknya bahwa majelis hakim dengan mengacu pada Keputusan Pasamuhan Agung III MUDP Bali, menimbang bahwa istri mempunyai hak yang sama terhadap guna kaya, dan tersirat bahwa harta guna kaya tersebut adalah milik bersama, dan sebagiannya adalah hak dari istri. Putusan tersebut 
merupakan salah satu bukti bahwa dewasa ini norma hukum waris adat yang mengakui kedudukan janda atas harta bersama masih relevan untuk diberlakukan.

Perkembangan kedudukan janda sebagai ahli waris pertama-tama berawal dari Jawa, dan wilayahwilayah lainnya menyusul setelah hilangnya keraguan di pihak para hakim Mahkamah Agung (Daniel S. Lev, 2018 : 15). Putusan Mahkamah Agung No 110 K/Sip/1960 pada intinya menyatakan bahwa menurut hukum adat, seorang janda adalah juga menjadi ahli waris almarhum suaminya (H. Hilman Hadikusuma, 2015 : 140). Begitu pula halnya dengan Putusan Mahkamah Agung No. 100 K/Sip/1967 tanggal 14 Juni 1968 yang bahwa:

"Mengingat pertumbuhan
masyarakat dewasa ini menuju
kearah persamaan kedudukan
antara pria dan wanita dan
pengakuan janda sebagai ahli
waris, Mahkamah Agung
membenarkan pertimbangan dan
putusan Pengadilan Tinggi yang
menetapkan bahwa dalam hal
meninggalnya seorang suami

\begin{abstract}
dengan meninggalkan seeorang janda, seorang anak laki-laki, dan seorang anak perempuan, janda berhak atas separoh dari harta bersama, sedang sisanya dibagi antara janda dan kedua anaknya masing-masing mendapat sepertiga bagian (di daerah Kabanjahe Sumatera Timur).”
\end{abstract}

Dari putusan-putusan tersebut di atas, dapat dipahami bahwa pada dasarnya memang telah terjadi pergeseran pandangan dan sosial budaya terkait norma hukum waris adat patrilineal yang semula hanya mengakui anak laki-laki sebagai ahli waris. Sederhananya, dengan adanya permasalahan yang diajukan ke pengadilan maka dapat diartikan bahwa ada beberapa kalangan tertentu yang sudah memiliki pergeseran pandangan mengenai norma adat yang diakuinya. Kemudian, apabila terdapat hakim yang mengakui pergeseran norma tersebut, maka dapat diartikan bahwa menurut hukum telah terdapat pergeseran norma hukum waris adat patrilineal yang dapat diberlakukan setidak-tidaknya bagi kalangan 
tertentu atau pihak yang berperkara. Hal itu dikarenakan pertimbangan hakim itu sudah telah didahului dengan penggalian nilai-nilai oleh hakim secara matang dengan disesuaikan pada kebijaksanaan hakim serta asas-asas hukum adat yang mengutamakan keadilan, kebersamaan, dan kerukunan. Pasal 5 UU Kekuasaan Kehakiman No. 49 Tahun 2009 mengatur bahwa hakim menggali, mengikuti, dan memahami nilai-nilai hukum an rasa keadilan yang berlaku. Dalam Seminar Hukum Nasional Tahun 1963 dapat disimpulkan bahwa hakim membimbing perkembangan hukum tidak tertulis melalui yurisprudensi ke arah keseragaman hukum yang seluas-luasnya dan ke arah sistem parental, yang mana poin terakhir tersebut juga ditegaskan dalam Seminar Hukum Adat di Yogyakarta Tahun 1975 (Edo Hendrako, 2015:88). Oleh karena itu, putusan tersebut dapat menjadi suatu acuan hukum yang menyatakan adanya pergeseran nilai-nilai hukum waris dalam masyarakat adat patrilineal.

Di sisi lain perlu dipahami bahwa putusan-putusan hakim tersebut tidak semata-mata membuat norma hukum waris adat patrilineal berubah seutuhnya untuk seluruh kalangan. Terdapat beberapa alasan atas hal tersebut. Pertama, persoalan waris adat merupakan persoalan privat yang sifatnya sangat bergantung pada kondisi dan keadaan secara kasus per kasus (hukum yang sifatnya sensitif dan bergantung pada kesadaran dan budaya hukum subjek hukum itu sendiri). Terlebih, hukum waris adat merupakan living law (Venika Aprilia Sembiring, Sri Wahyu Ananingsih, Triyono, 2016:2) yang tidak tertulis, tidak rigid, dan dinamis. Putusan hakim terkait persoalan waris adat lebih difokuskan kepada kondisi secara kasus per kasus (case by case) dari pihak yang berperkara, karena hukum adat bergantung pada kondisi dan keadaan budaya dari tiap-tiap masyarakat atau kelompok yang bersangkutan. Dengan demikian, suatu putusan mengenai hukum waris adat seyogianya tidak sepenuhnya dapat menggambarkan atau mencakup seluruh kaidah hukum yang berlaku bagi semua 
jenis kalangan masyarakat patrilineal dimana masing-masing wilayah dan kalangan masyarakat itu sendiri memiliki pandangan, gaya hidup, budaya, serta nilai hukum yang berbeda. Sebagai contoh, apabila suatu putusan menetapkan adanya kedudukan janda dan anak perempuan sebagai ahli waris dikarenakan mereka merupakan keluarga yang telah lama bermigrasi atau karena wilayah mereka bertempat tinggal telah mengalami modernisasi yang kuat sehingga ketaatan terhadap ikatan komunal dan hukum adat tidak lagi berlaku sepenuhnya, maka putusan hakim tersebut seyogianya tidak dapat secara utuh diterapkan terhadap masyarakat patrilineal wilayah lainnya atau kalangan/kelompok masyarakat lainnya yang memang masih mengakui dan mempraktekan hukum adat secara lebih kuat.

Meskipun putusan Mahkamah Agung tanggal 1 Nopember 1961 Nomor 179/K/Sip/1961 menyatakan bahwa perubahan norma hukum waris adat patrilineal itu berlaku untuk seluruh Indonesia, kita tetap perlu memahami bahwa Negara
Kesatuan Republik Indonesia pada kenyataannya sangat pluralistik dengan berbagai keragaman budaya dan nilai adat yang berbeda-beda yang mana sepatutnya perlu dihargai sebagai kekayaan bangsa ini. Pasal 18B ayat (2) Undang-Undang Dasar 1945 dengan tegas juga menyatakan bahwa hukum adat serta hak-hak tradisional tetap diakui selama masih hidup dan sesuai dengan perkembangan serta prinsip Negara Kesatuan Republik Indonesia. Dari pasal tersebut jelas bahwa apabila terdapat perkembangan hukum adat maka hal itu harus diakomodir, namun apabila masih terdapat beberapa kalangan atau masyarakat yang tetap mempraktekan adat itu sendiri maka hal itu juga tetap harus dihormati. Dalam hal itu diperlukan peran hakim untuk benar-benar menggali nilai yang berlaku pada masyarakat atau kalangan yang bersangkutan sesuai Pasal 5 UU Kekuasaan Kehakiman No. 49 Tahun 2009. Beberapa permasalahan dari pihak-pihak tertentu yang muncul ke pengadilan tidak dapat menggambarkan keberlakuan menyeluruh dari hukum adat itu 
sendiri. Dengan demikian, putusanputusan tersebut tidak dapat serta merta menjadi norma hukum yang utuh menyeluruh terhadap seluruh kalangan dan diberlakukan secara mutlak sebagai kaidah hukum yang berlaku, namun di sisi lain tetap menggambarkan adanya pergeseran norma hukum waris adat patrilineal. Hukum waris adat di Indonesia saat ini masih bersifat pluralistik, proses unifikasi hukum adat seperti melalui putusan atau yurisprudensi, tetap sulit direalisasikan mengingat hukum waris adat bersifat sensitif (Sonny Dewi Judiasih dan Efa Laela Fakhriah, 2018 : 329).

Alasan kedua, yurisprudensi merupakan salah satu sumber hukum formiil di Indonesia namun keberlakuannya tidak bersifat mengikat dan mutlak. Tidak seperti halnya dengan yurisprudensi di negara common law yang mengikat untuk diikuti oleh hakim-hakim berikutnya (the binding force of precedent), yurisprudensi di Indonesia tidak mutlak harus diikuti oleh hakim-hakim (persuasive force of precedent). Dengan demikian, kaidah hukum yang tertulis dalam yurisprudensi tersebut tidak serta merta berlaku secara mutlak sebagai kaidah hukum yang wajib diikuti oleh hakim lainnya dan/atau dalam seluruh permasalahan waris adat patrilineal lainnya. Yurisprudensi memiliki sifat dan keberlakuan yang berbeda dari peraturan perundangundangan. Selain itu, pada kenyataannya terdapat beberapa putusan yang tidak memiliki pertimbangan dan pendapat yang sama dengan putusan-putusan tersebut di atas.

Beberapa contoh di antaranya adalah Putusan Pengadilan Tinggi Denpasar tanggal 22 Juli 1972 Nomor 105/PTD/107 (Ni Luh Gede Praresti Dangin, 2015 : 11) dan Putusan Mahkamah Agung tanggal 1 Juni 1955, No. 53/K/Sip/1952 yang menyatakan bahwa apabila seorang wafat meninggalkan anak laki-laki maka ia adalah satu-satunya ahli waris (H. Hilman Hadikusuma, 2015 : 135). Contoh lainnya adalah Putusan Mahkamah Agung tanggal 25 Oktober 1958 No. 54/K/Sip/1958 yang menyatakan "menurut hukum adat Batak (yang bersifat patriarchal) segala harta yang timbul 
dalam perkawinan adalah milik suami (Hilman Hadikusuma, 2015 : 61). Salah satu putusan terbaru yang tidak mengakui kedudukan janda sebagai ahli waris menurut adat patrilineal adalah sebagaimana dalam putusan Pengadilan Negeri Singaraja Nomor 367/Pdt.G/2016/PN.Sgr yang menyatakan bahwa janda sebagai "Balu Luh" dalam adat Bali bukan sebagai ahli waris, tetapi dapat/berhak menikmati hasil dari harta warisan. Putusan-putusan tersebut membuktikan bahwa pergeseran norma hukum waris adat patrilineal, baik dahulu maupun saat ini, tidak semata-mata diakui oleh seluruh hakim dan diberlakukan bagi semua kasus dan kalangan masyarakat.

Terlepas dari penjelasan di atas, keberadaan yurisprudensi merupakan suatu tolak hukum pengakuan atas pergeseran norma hukum waris adat patrilineal yang dapat dijadikan sebagai acuan hukum bagi hakim lainnya maupun masyarakat khususnya ketika menghadapi suatu persoalan dengan kondisi atau latar belakang pertimbangan yang serupa. Meskipun suatu yurisprudensi atau putusan terdahulu tidak memiliki kekuatan mengikat di Indonesia, namun secara langsung maupun tidak langsung kaidah hukum yang diterapkan dalam suatu yurisprudensi akan mempengaruhi pandangan dan kaidah hukum yang berlaku, terlebih mengingat hukum adat bersifat tidak tertulis dan dinamis sehingga lebih mudah berubah-ubah dibandingkan peraturan perundang-undangan. Dalam hal hubungan antara hukum waris adat dan putusan hakim, maka menurut Daniel S.Lev, diantaranya terdapat hubungan dipengaruhi dan mempengaruhi (Daniel S. Lev, 2018 : 30). Sifat dipengaruhi timbul karena, isi putusan hakim dipengaruhi dari pergeseran norma hukum waris adat yang diakibatkan perubahan nilai-nilai maupun pandangan yang berlaku. Sifat mempengaruhi timbul karena putusan tersebut dapat berlaku sebagai yurisprudensi yang kemudian dapat saja diakui oleh hakim lainnya sebagai kaidah hukum yang berlaku. Yurisprudensi juga dapat mempengaruhi pemikiran hakim lainnya serta mempengaruhi perkembangan dan perubahan nilai- 
nilai maupun pola pikir masyarakat adat patrilineal untuk memberi pengakuan terhadap kedudukan anak perempuan dan janda sehingga menimbulkan perubahan norma hukum waris adat patrilineal.

\section{Simpulan}

Berdasarkan pembahasan di atas, maka dapat ditarik kesimpulan sebagai berikut:

1) Pergeseran norma hukum waris adat patrilineal terjadi dengan diakuinya hak dan kedudukan anak perempuan serta janda dalam beberapa wilayah atau kelompok tertentu, yang mana seharusnya sistem pewarisan patrilineal hanya mengakui anak laki-laki sebagai ahli waris. Pergeseran tersebut timbul karena adanya perubahan nilai dan pandangan sosial budaya, yang diakibatkan karena pengaruh agama, modernisasi, urbanisasi, migrasi, maupun meningkatnya peran perempuan dalam membangun kesejahteraan keluarga.

Pergeseran norma hukum waris adat patrilineal tersebut sesuai dengan ciri dari hukum adat itu sendiri yakni bersumber dari keyakinan dan kebiasaan masyarakat, dinamis, dan tidak tertulis, dengan mengutamakan asas-asas seperti kebersamaan, kerukunan, serta keadilan.

2) Terdapat beberapa yurisprudensi yang mengakui adanya pergeseran norma hukum waris adat patrilineal terkait hak janda dan anak perempuan dalam pewarisan dalam beberapa kasus tertentu, sehingga hal itu menjadi bukti adanya pergeseran pandangan dan norma bagi beberapa kalangan atau kelompok masyarakat tertentu. Suatu putusan diputus secara kasus per kasus dan yurisprudensi di Indonesia tidak bersifat mengikat (persuasive force of precedent). Indonesia masih memiliki keragaman budaya serta nilai adat yang berbeda antara satu daerah atau satu kelompok dengan yang lainnya, sehingga kaidah hukum dalam yurisprudensi tersebut bukan merupakan kaidah hukum yang mutlak berlaku bagi 
seluruh masyarakat patrilineal. Terlepas dari hal tersebut yurisprudensi merupakan suatu acuan hukum yang dapat dijadikan bahan pertimbangan oleh hakim dan masyarakat, yang dapat mempengaruhi putusan hukum dan pandangan masyarakat sehingga berpengaruh pada arah perkembangan kaidah hukum waris adat patrilineal.

\section{Saran}

1) Perlu adanya pengkajian dan penelitian lebih lanjut yang berkesinambungan terkait perkembangan hukum waris adat patrilineal di berbagai wilayah dan kalangan masyarakat untuk mengetahui sejauh mana norma hukum waris adat tersebut masih kental diberlakukan. Hal ini mengingat hukum waris adat berasal dari keyakinan dan budaya masyarakat (living law), tidak tertulis, dan dinamis. Penelitian dan pedoman ini diperlukan dikarenakan hukum waris adat juga merupakan suatu hukum yang berlaku bagi golongan masyarakat tertentu dalam hal pewarisan sehingga perlu dipahami oleh masyarakat dan para praktisi hukum dalam menyelesaikan persoalan hukum.

2) Dalam memutus perkara hakim perlu benar-benar menggali dan memahami nilai-nilai hukum adat yang berlaku dengan disesuaikan pada perkembangan pandangan, sosial budaya, serta kebutuhan dari subjek yang bersangkutan. Hal itu sesuai dengan Pasal 5 UU Kekuasaan Kehakiman Nomor 49 Tahun 2009. Dalam memutus suatu perkara, hakim perlu berhati-hati dalam menggali nilai-nilai tersebut dan memilih acuan yurisprudensi yang ada, agar kaidah hukum yang diberlakukan sesuai dengan apa yang dibutuhkan serta menjadi living law dari pihak/kalangan yang bersangkutan terlebih suatu putusan juga merupakan produk hukum yang harus dapat dipertanggungjawabkan karena dapat dijadikan suatu acuan kaidah yang berlaku. 


\section{Daftar Pustaka}

\section{Buku}

Hadikusuma, Hilman. 2015, Hukum Waris Adat. Cetakan ke-8. Bandung: PT. Citra Aditya Bakti.

Judiasih, Sonny Dewi, Kusmayanti, Hazar dan Yuanitasari, Deviana. 2020, Pergeseran Norma Hukum Waris Adat di Indonesia. Jatinangor: UNPAD Press.

Karim, Khalil Abdul. 2003, Syari'ah: Sejarah Perkelahian Pemaknaan, diterjemahkan oleh Kamran As'ad. Yogyakarta: LkiS.

Lev, Daniel.S. 2018, Hukum Dan Politik Di Indonesia, Jakarta: Penerbit LP3ES

Perangin, Effendi. 2018, Hukum Waris. Cetakan ke-15, Jakarta: Rajagrafindo Persada.

Subekti, R. 1991, Hukum Adat Indonesia dalam Yurispridensi Mahkamah Agung, Bandung: Alumni.

\section{Jurnal}

Dangin, Ni Luh Gede Praresti Dangin. 2015, "Kedudukan Hak Mewaris Wanita Hindu Dalam Sistem Hukum Adat Waris di Bali”, Jurnal Mahasiswa Fakultas Hukum Universitas Brawijaya. diunduh dari https://www.neliti.com/publ ications/35307/kedudukan- hak-mewaris-wanita-hindudalam-sistem-hukum-adatwaris-di-bali pada tanggal 21 September 2020 pukul 14.10 WIB.

Hendrako, Edo. 2015, "Hak Waris Anak Perempuan Terhadap Harta Peninggalan (Studi Kasus Putusan MA RI Nomor 4766/Pdt/1998)", Jurnal Lex Privatum Vol. III No.1, Januari-Maret.

Jayus, Jaja Ahmad. 2019, "Eksistensi Pewarisan Hukum Adat Batak : Kajian Putusan Nomor 1/PDT.G/2015/PN.Blg dan Nomor 439/PDT/2015/PTMdn", Jurnal Yudisial Vol. 12.No. 2. Agustus

Judiasih, Sonny Dewi dan Fakhriah, Efa Laela. 2018, "Inheritance Law System: Considering The Pluralism of Customary Law in Indonesia", Padjajaran Journal of Law Vol.5 No.2.

Muzainah, GT. 2014, "Prinsip Hukum Kedudukan Perempuan Dalam Hukum Waris Adat Masyarakat Banjar", Jurnal Studi Gender dan Anak Vol II No.1. Januari-Juni.

Nangka, Bravo. 2019, "Penyelesaian Sengketa Berdasarkan Hukum Waris Adat Berdasarkan Sistem Kekerabatan", Jurnal Lex Privatum Vol. VII No. 3 Maret. 
Sembiring, Venika Aprilia, Ananingsih, Sri Wahyu, dan Triyono, "Perkembangan Pewarisan Masayrakat Adat Batak Karo di Kabupaten Karo, Sumatera Utara", Diponegoro Law Journal Vol. 5.No. 3, diunduh dari https://media.neliti.com/med ia/publications/19210-IDperkembangan-pewarisanmasyarakat-adat-batak-karodi-kabupaten-karosumatera-uta.pdf pada tanggal 22 September 2020 pukul 14.30 WIB.

Sulastriyono dan Pradhani, Sartika Intaning. 2018, "Pemikiran Hukum Adat Djojodigoeno dan Relevansinya Kini”, Jurnal Mimbar Hukum Universitas Gadjah Mada Vol 30.No. 3.

Utari, Ni Ketut Sri. 2006, "Mengikis Ketidakadilan Gender dalam Masyarakat Adat Bali”, Disajikan (untuk urun pendapat) dalam Temu Ilmiah II Asosiasi Pengajar dan Peminat Hukum Berspektif Gender se Indonesia (APPHGI) tanggal 18-20 September 2006. Surabaya. diunduh dari ojs.unud.ac.id tanggal 26 September 2020 pukul 12.39 WIB.

Wijaya, Wahyu Satria Wana Putra, Prasetyo, Agung Basuki dan Triyono. 2016 , "Perkembangan Kedudukan Ahli Waris Perempuan
Dalam Sistem Kekerabatan Patrilineal Di Denpasar Bali (Pasca Keputusan Nomor 01/KEP/PSM-3/MDP /X/2010 tentang Hasil-Hasil Pasamuhan Agung III MUDP Bali)", Diponogoro Law Review Vol. 5 No. 2.

\section{Peraturan Perundang-undangan}

Undang-Undang Dasar 1945

Undang-undang No. 49 Tahun 2009
tentang
Kehakiman

